\begin{tabular}{c|l|l|l}
$\begin{array}{c}\text { Case Reports in } \\
\text { NeUrology }\end{array}$ & $\begin{array}{l}\text { Case Rep Neurol 2010;2:118-121 } \\
\text { DOl: 10.1159/000320925 }\end{array}$ & $\begin{array}{l}\text { Published online: } \\
\text { September 12, 2010 }\end{array}$ & $\begin{array}{l}\text { O 2010 S. Karger AG, Basel } \\
\text { ISSN 1662-680X } \\
\text { www.karger.com/crn }\end{array}$ \\
\hline
\end{tabular}

\title{
Chronic Intraventricular Encapsulated Hematoma in an Adult: A Case Report
}

\author{
E. Kechagias ${ }^{\mathrm{a}} \quad$ C. loakimidou ${ }^{\mathrm{b}} \quad$ N. Georgakoulias ${ }^{\mathrm{a}}$ \\ A. Seretis $^{\mathrm{a}}$ G. Kontogeorgos ${ }^{\mathrm{b}}$ \\ Departments of a Neurosurgery and ${ }^{\mathrm{b}}$ Pathology, General Hospital of Athens \\ 'G. Gennimatas', Athens, Greece
}

\section{Key Words}

Chronic intraventricular encapsulated hematoma - Intraventricular mass - Transcallosal approach · Cranial nerve palsy

\begin{abstract}
This case report is a presentation of a chronic intraventricular encapsulated hematoma in an adult who presented with gait disturbance, fever, palsy of N. III, N. VI and N. VII, and photophobia. Ophthalmoscopy revealed a bilateral papilledema. Computed tomography scans and magnetic resonance imaging revealed an intraventricular mass in the lateral ventricle. Preoperative diagnosis could not rule out a neoplasm. The lesion was totally removed with open surgery and was found to be a chronic intraventricular encapsulated hematoma. A chronic intraventricular encapsulated hematoma is a rare entity. After the removal of the mass, the clinical symptoms of the patient gradually resolved.
\end{abstract}

\section{Introduction}

Chronic intraventricular encapsulated hematoma is a rare entity and the exact mechanisms of capsule formation, progressive expansion and resolution have remained uncertain [1]. Here, the hematoma was in the lateral ventricle with a significant mass effect. The lateral ventricles are delimited by a number of vital anatomic structures. Damage to any of these vascular or neural elements from direct compression, ischemia or invasion can result in a multitude of signs and symptoms. These include cranial nerve deficits, features of elevated intracranial pressure from hydrocephalus, changes in higher cognitive function or even autonomic dysregulation.

Computed tomography (CT) and magnetic resonance imaging (MRI) are excellent diagnostic tools and are essential in surgical planning. Since a neoplasm could not be ruled out preoperatively, the lesion was totally removed by right frontal craniotomy with 
a transcallosal approach in order to eliminate the mass effect. The general medical condition of the patient is another important consideration in defining surgical strategy.

After an extensive review of the literature only very few cases were found. A case of chronic intraventricular encapsulated hematoma is presented along with clinical, radiological and surgical features.

\section{Case Report}

A 30-year-old male was admitted to our hospital in October 2008 with a 4-day history of fever, photophobia, diplopia and cervical pain. On admission, neurologic examination revealed palsy of the right abducens nerve (Cr. N. VI), oculomotor nerve (Cr. N. III) with diplopia and peripheral palsy of the facial nerve (Cr. N. VII). He had no history of head injury or arterial hypertension before admission. Fundoscopy detected bilateral papilledema. The patient had a normal medical history. The brain CT scan showed a round-shaped homogenous mass in the lateral ventricle with a peripheral zone of high density, mild perifocal edema and a ring enhancement with mass effect. Brain MRI showed an extraaxial round-shaped lesion in the middle line, arising from the roof of the third ventricle with definite edges and with a significant mass effect. The lesion appeared with high signal intensity on T1- and T2weighted images (fig. 1). After contrast injection, ring enhancement of the lesion could be observed. Surgery was performed via right frontal craniotomy and an interhemispheric, transcallosal approach. A yellowish mass was found with glistering appearance and a hard wall that was difficult to be operated without micro-knifes and ultrasonic aspirator. The mass was filled with engine oil-like fluid and removed totally without difficulties because of the plane with the surrounding tissue. Histological examination revealed a hematoma which was consistent with early development of granulation tissue, neovascularization, accumulation of fibroblasts, histiocytes and hemosiderin deposits (fig. 2). No neoplastic elements were present. Postoperatively, the patient's condition gradually improved (fig. 3 ), and a neuropsychological examination revealed no memory disturbances. He was discharged after 6 days.

\section{Discussion}

Chronic encapsulated intracerebral hematoma $(\mathrm{CEIH})$ is a rare lesion which is believed to be caused by angiographically occult vascular malformations (AOVM) such as arteriovenous malformation (AVM), venous angiomas, cavernous malformations, capillary telangiectasia, mixed or unclassified angiomas $[2,3]$. Chronic intraventricular encapsulated hematoma is a rarer entity than CEIH. The common feature of the two lesions is the formation of a capsule. The mechanism, however, remains unclear in most cases [1-7]. MRI can be used to demonstrate that a lesion is only a hematoma and is valuable in follow-up and in differentiating these hematomas from neoplasms.

Differential diagnosis by location includes astrocytoma, colloid cyst, craniopharyngioma, teratoma, choroid plexus papilloma, cysticercosis, dermoid, choroids plexus carcinoma and AVM. In our case, the preoperative diagnosis was a neoplasm. However, the final diagnosis relies on the histological examination of the lesion. 


\begin{tabular}{c|l|l|l}
$\begin{array}{c}\text { Case Reports in } \\
\text { NeUrology }\end{array}$ & $\begin{array}{l}\text { Case Rep Neurol 2010;2:118-121 } \\
\text { DOl: 10.1159/000320925 }\end{array}$ & $\begin{array}{l}\text { Published online: } \\
\text { September 12, 2010 }\end{array}$ & $\begin{array}{l}\text { O 2010 S. Karger AG, Basel } \\
\text { ISN 1662-680X } \\
\text { www.karger.com/crn }\end{array}$ \\
\hline
\end{tabular}

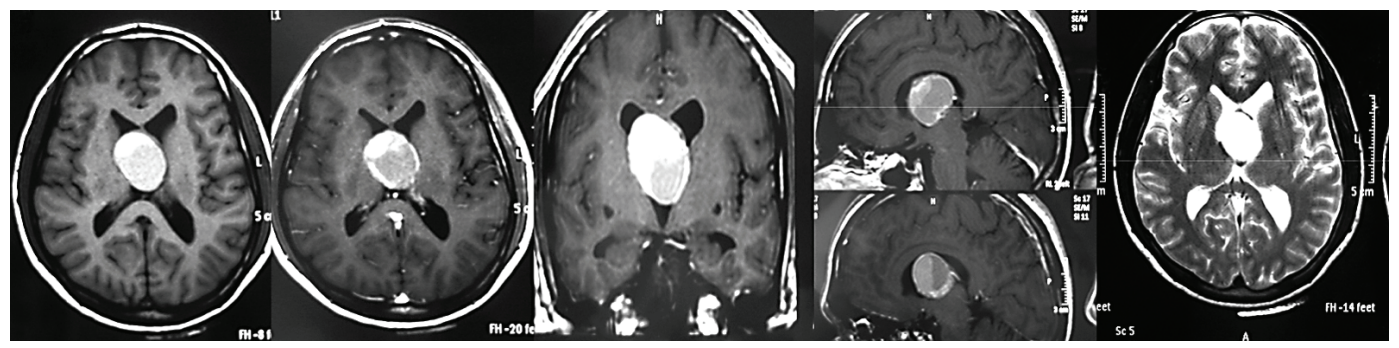

Fig. 1. Preoperative T1-weighted MR image. Axial section of preoperative T1-weighted MR image.

Coronal section and sagittal section of preoperative Gd-enhanced T1-weighted MR image. Axial section of preoperative T2-weighted MR image. Axial section.

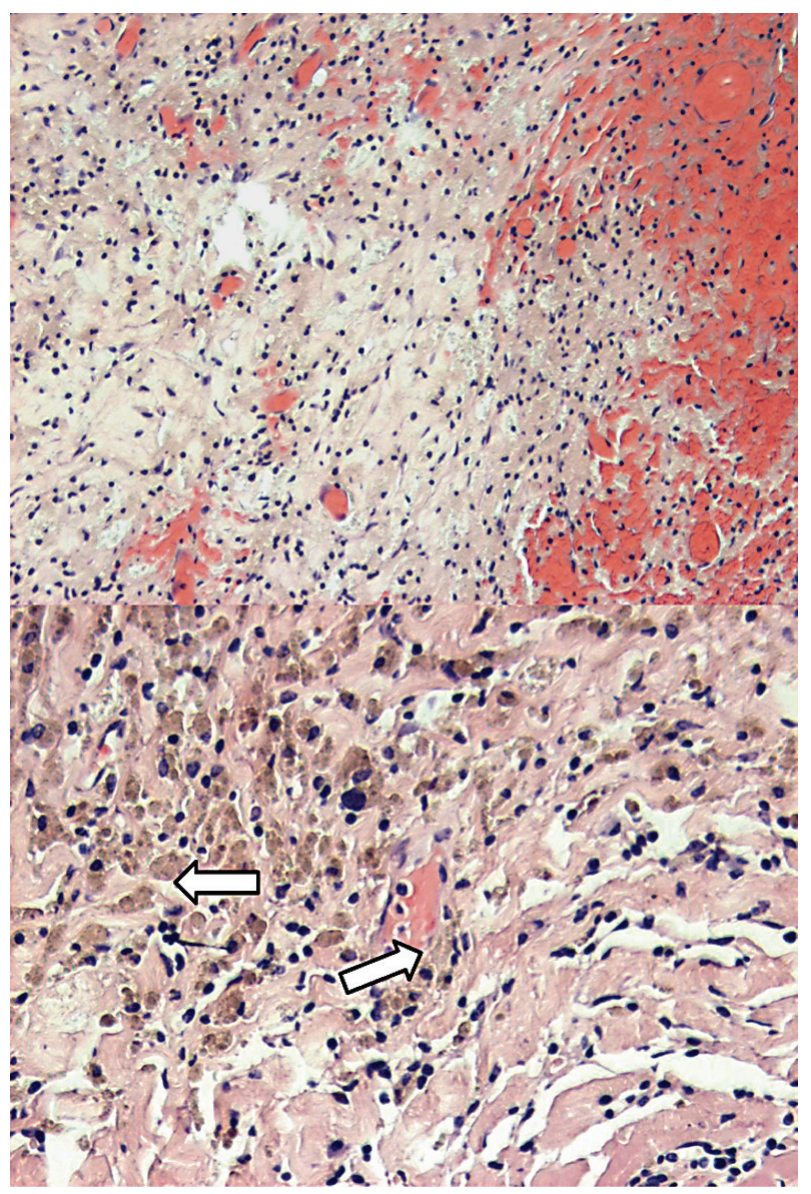

Fig. 2. Hematoma with early development of granulation tissue, accumulation of fibroblast and histiocytes and newly formed vascular channels (right arrow) and histiocytes with hemosiderin deposits (left arrow). 


\begin{tabular}{l|l|l|l} 
Case Reports in & $\begin{array}{l}\text { Case Rep Neurol 2010;2:118-121 } \\
\text { DOl: 10.1159/000320925 }\end{array}$ & $\begin{array}{l}\text { Published online: } \\
\text { September 12, 2010 }\end{array}$ & $\begin{array}{l}\odot \text { ISSN 1662-680X } \\
\text { www.karger.com/crn }\end{array}$ \\
\hline
\end{tabular}

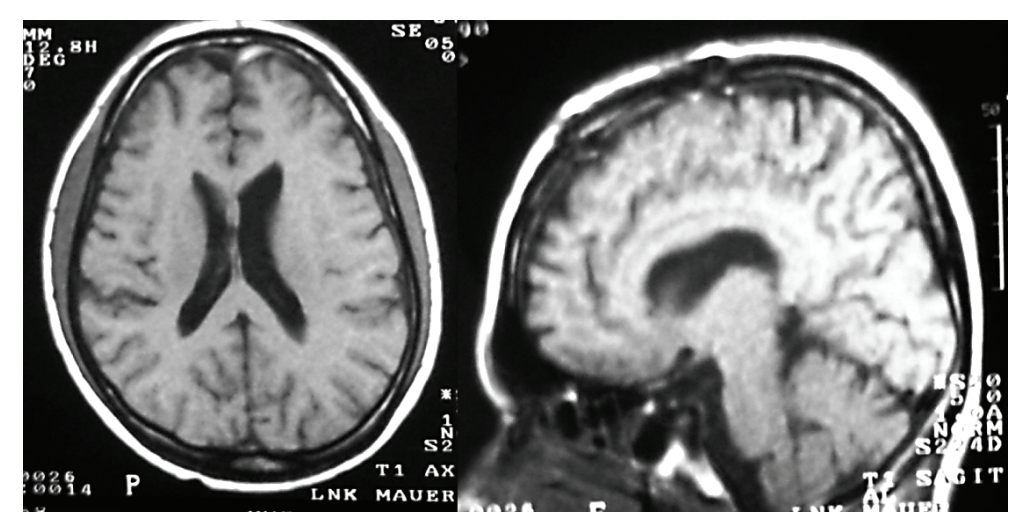

Fig. 3. Postoperative T1-weighted MR image. Axial and sagittal section.

\section{References}

$\checkmark 1$ Ooba H, Kamida T, Isono M, Kobayashi H, Karashima A, Yamashita M: Chronic intraventricular encapsulated hematoma presenting unique radiological features: a case report. Surg Neurol 2003;59:23-27.

- Greiner-Perth R, Neaubaouer U, Schenke H: Chronic encapsulated intracerebral hematoma - a well-defined disease. Report on two cases and review of the literature. Neurosurg Rev 1997;20:231-238.

-3 Roda JM, Carceller F, Pérez-Higueras A, Morales C: Encapsulated intracerebral hematomas: a defined entity. Case report. J Neurosurg 1993;78:829-833.

-4 Ilkko E, Pyhtinen J, Reponen J: Chronic encapsulated intracerebral hematoma. Neuroradiology 1996;38:551554.

5 Lin SZ, Shih CJ, Wang YC, Tsai SH: Intracerebral hematoma simulating a new growth. Surg Neurol 1984;21:459-464.

6 Monma S, Ohno K, Hata H, Komatsu K, Ichimura K, Hirakawa K: Cavernous angioma with encapsulated intracerebral hematoma: case report. Surg Neurol 1990;34:245-249.

-7 Weber W, Henkes H, Jänisch W, Vogelsang F, Kühne D: Chronic encapsulated intracerebral hematoma. Nervenarzt 2000;71:995-999. 